\title{
Production performance and egg quality of White Rock laying hens fed diets containing whole linseed
}

\author{
H. Khatun ${ }^{1 *}$, M.N. Islam ${ }^{2}$, M.A. Rashid ${ }^{1}$, M.Y. Ali ${ }^{1}$ and M.S.K. Sarker ${ }^{1}$ \\ ${ }^{1}$ Poultry Production Research Division, Bangladesh Livestock Research Institute, ${ }^{2}$ Director General, \\ Bangladesh Livestock Research Institute, Savar, Dhaka-1341, Bangladesh
}

\begin{abstract}
This study was conducted to know the production performance of laying hen by using different graded level of linseed. At 56 weeks of age, a total of 160 laying hens were raised up to 63 weeks of age. All hens were fed a basal corn soyabean meal diet. The experiment was allowed 4 dietary treatments $\left(\mathrm{T}_{0}\right.$, no addition of whole linseed in the basal diet; $T_{1}$, addition of $5 \%$ whole linseed; $T_{2}$, addition of $10 \%$ whole linseed and $\mathrm{T}_{3}$, addition of $15 \%$ whole linseed) with 5 replications and per replication contains eight hens. Egg production, feed intake, egg weight of each treatment was recorded. Egg samples were collected and analyzed for egg quality. The results showed that egg production and egg mass $(\mathrm{kg})$ exhibited for all dietary treatment groups were unaffected $(\mathrm{P}>0.05)$ by feeding linseed to the laying hens. Feed Conversion Ratio (FCR) was found significant difference within the four dietary group $(\mathrm{P}<0.05)$. Egg quality aspects such as yolk weight, egg weight, $\mathrm{HU}$ and yolk index were not differed significantly ( $\mathrm{P}>0.05)$ among treatments. A trénd for lower yolk weight was observed in birds fed $10 \%$ linseed, where as the highest yolk weight percentage was recorded in control diet. There was no statistical difference among the different diets for yolk index. The results of the present trial suggested that feeding linseed to the laying hens has no detrimental effects on egg production and egg quality.
\end{abstract}

(Key words: Production performance, laying hen and linseed)

\section{Introduction}

Linseed meals fed to laying hens as a source of protein and energy. Many consumers are looking for convenient way to incorporate fatty acid into their diets. Consuming eggs enriched with omega 3 fatty acids is a convenient way to do so. An increase in the omega 3 fatty acid content of eggs especially alpha linolenic acid (ALA), when laying hens are fed linseed oil or linseed (Bean and Leeson,' 2003). Overfeeding linseed can cause problems of hens due to containing sticky compounds that stop the hen from digesting some of the nutrient in the diet. Feeding too much linseed can decreases production, egg size, body weight and shell thickness (Manitoba agriculture and food, 1999). Several authors reported both short and long term feeding trials using linseed in laying hen diets (Novak \& Scheideler, 2001) with inclusion from 5 to $30 \%$ (Cherian, 2008). The drawbacks of including higher levels $(>8 \%)$ of linseed have been associated with its various components affecting palatability, feed intake, egg production, egg

*Corresponding author; hkr.7519@gmail.com

Bang. J. Livs. Res. Vol. 20 (1 \& 2), 2013: P. 48-53 ISSN 1022-3851 
quality and organoleptic aspects (Bhatty, 1995). However, Bean and Leeson (2003) demonstrated that feeding $10 \%$ linseed did not impact on egg production if the linseed is phased into the diet over a three week period starting at 28 weeks of age. However, laying performance has not been much emphasized in such studies. Contradictory results on the performance of layers fed linseed as a source of n-3 PUFA have been reported (Ahmad et al. 2013). Some studies indicate that there are no differences in egg production, egg weight, egg shell thickness and albumen height when layers are fed 0 or $10 \%$ linseed (Bean and Leeson, 2003).

Aymond and vanelswyk (1995) observed a decrease in egg production in layers fed 15 $\%$ linseed; however, other authors reported an increase in egg production when hens were fed 5, 1:0 and 20\% linseed (Scheideler and Froning, 1996; Beynen, 2004). Similarly, Sosin et al., (2006) also indicated reduced egg weight when layers were fed linseed. Bean and Leeson (2003) found yolk weight reduction in layers consuming linseed, whereas Sosin et al., (2006) reported that feeding linseed to layers had no effect on the yolk weight. There is little information available on the performance of layer diet containing linseed as a source of n-3 PUFA. Thus, the present study was designed to investigate the effects of feeding linseed on the performance and egg characteristics of layer.

\section{Materials and Methods}

\section{Experimental design, birds housing and management}

At 56 weeks of age, a total of 160 White Rock layers were selected and randomly assigned to each treatment. In a completely randomized design was applied with four dietary treatment: 1) $T_{0}$ (no addition of whole linseed in the basal diet,); 2) $T_{1}$ (addition of $5 \%$ whole linseed); 3) $\mathrm{T}_{2}$ (addition of $10 \%$ whole linseed) and 4) $\mathrm{T}_{3}$ (addition of 15\% whole linseed). Each treatment was replicated five times and eight birds were allotted per replication. The hens were housed in individual cages and identical care and management were provided to all the treatment groups. All dietary treatments were iso-caloric and iso-nitrogenous (Table 1). Hens had ad libitum access to feed and water and a lighting program of $16 \mathrm{~L}: 8 \mathrm{D}$ was applied to all treatment groups throughout the study.

\section{Production parameters and egg quality characteristics}

Production parameter (egg production, egg mass, feed intake and FCR) was measured from 56 to 63 week of age. Daily egg production per replicate cage was recorded, and at the end of each experimental week, the total number of eggs laid/bird/week was calculated. Eggs laid per replicate were weighed daily and at the end of experimental week, the average weight for that particular week was calculated. Data were used to calculate egg mass (number of eggs multiplied by egg weight) per bird per week. 
Table 1. Ingredients and nutrient composition of layer diets

\begin{tabular}{lcccc}
\hline \multirow{2}{*}{ Ingredients $(\mathrm{kg})$} & \multicolumn{4}{c}{ Dietary treatments } \\
\cline { 2 - 5 } & $\mathrm{T}_{0}$ & $\mathrm{~T}_{1}$ & $\mathrm{~T}_{2}$ & $\mathrm{~T}_{3}$ \\
\hline Maize & 51 & 43.5 & 35.0 & 32.0 \\
Rice polish & 15.0 & 14.0 & 17.5 & 15.0 \\
Wheat bran & 5.0 & 8.75 & 10.75 & 15.25 \\
Protein concentrate & 7.7 & 2.5 & 3.5 & 4.0 \\
Soyabean meal & 13.05 & 18.0 & 15.0 & 11.0 \\
Linseed & 0.0 & 5.0 & 10.0 & 15.0 \\
Lime stone & 3.0 & 3.0 & 3.0 & 3.0 \\
Oyester shell & 4.5 & 4.5 & 4.5 & 4.0 \\
o Vitamin mineral premix & 0.25 & 0.25 & 0.25 & 0.25 \\
salt & 0.5 & 0.5 & 0.5 & 0.5 \\
Nutrient composition & & & & \\
ME (Kcal/kg) & 2741 & 2778 & 2762 & 2793 \\
CP (\%) & 17.41 & 17.29 & 17.52 & 17.38 \\
EE (\%) & 9.09 & 9.3 & 12.68 & 12.80 \\
Ash (\%) & 11.63 & 11.17 & 11.32 & 11.12 \\
CF (\%) & 3.10 & 3.5 & 4.91 & 3.96 \\
Ca (\%) & 3.32 & 3.06 & 3.23 & 3.19 \\
Av P (\%) & 0.27 & 0.20 & 0.23 & 0.25 \\
\hline
\end{tabular}

${ }^{\circ}$ Contain per kg: retinol, $3.6 \mathrm{mg}$; cholecalciferol, $0.125 \mathrm{mg}$; tocopherol, $50 \mathrm{mg}$; menadione, $3 \mathrm{mg}$; thiamine, $2 \mathrm{mg}$; riboflavin, $6 \mathrm{mg}$; pyridoxine, $4 \mathrm{mg}$; cyanocobalamin, $0.025 \mathrm{mg}$; biotin, $0.15 \mathrm{mg}$; pantothenicacid, $20 \mathrm{mg}$; folic acid, $2 \mathrm{mg}$; nicotimicacid, $7 \mathrm{mg}, \mathrm{Fe}, 66,720 \mathrm{mg} ; \mathrm{Cu}, 41,700 \mathrm{mg} ; \mathrm{Mn}, 83,400 \mathrm{mg} ; \mathrm{Zn}, 66,72 \mathrm{mg} ; \mathrm{I}, 834 \mathrm{mg} ; \mathrm{Se}, 250 \mathrm{mg}$. $\mathrm{ME}$, metabolizable energy; $\mathrm{CP}$, crude protein

Feed intake was measured on a weekly basis. Data on feed intake and egg mass were used to calculate feed conversion (feed intake/egg mass; $\mathrm{kg} / \mathrm{kg}$ ). At the end of each 2 weeks, two eggs from each replication were collected and used to determine egg quality characteristics ( $\mathrm{n}=10,2$ per replicate). The eggs were weighed, and yolks were separated and weighed. Albumin height was documented at 2 different sites by using a spherometer. Shell thickness was measured by using micrometer and Haugh units (HU) were calculated by the formula $\mathrm{HU}=100 \mathrm{log}$ $\left(\mathrm{H}+7.57-1.7 \mathrm{~W}^{0.37}\right.$ ) (Haugh, 1937).

\section{Statistical Analysis}

The experiment was used a completely randomized design. All recorded data were analyzed by General Linear Model (GLM) univariate procedure of SPSS computer program. The significant difference was isolated to calculated LSD using computer package SPSS (2006).

\section{Results and Discussion}

Egg production performance and feed consumption of different dietary groups are shown in Table 2. The results showed that 
increasing linseed in layer ration and thus decreased their body weight significantly $(\mathrm{P}<0.001)$. It might be due to linseed contains a dipeptide of glutamic acid and proline (linatine), which is present in the cotyledons $(100 \mathrm{mg} / \mathrm{kg})$ that adversely affects growth and food efficiency in birds because it acts as a pyridoxine antagonist (Madhusudhan et al., 1986). Mazza and Oomah (1995) reported that anti nutritional factors in linseed may have been the cause of the reduced chick growth. Egg production and egg mass ( $\mathrm{kg} /$ week) exhibited for all dietary treatment groups were not influenced ( $>0.05$ ) by feeding linseed to the laying hens. These results are in agreement with the findings of Baucells et al., (2000), Bean and
Leeson, (2003) and Mazalli et al., (2004) who reported no significant differences in egg production attributable to incorporation of linseed. However, feed intake was reduced $(0.10 \mathrm{~kg} /$ week/hen) in hens fed $5 \%$ linseed $(\mathrm{P}<0.01)$ as compared with the control. The highest feed intake was observed in hens fed the $T_{2}$ and $T_{3}$ diet group. FCR was found significant difference within the four dietary group $(\mathrm{P}<0.05)$. The best feed conversion occurred in hens fed the diets containing 5\% linseed and poor FCR record in 10 and $15 \%$ linseed containing diet. Similar result was also observer by Kratzer et al., (1996) who found higher levels of linseed in poultry diet caused noticeable reduction in feed efficiency.

Table 2. Egg production performance and feed consumption of different dietary groups

\begin{tabular}{|c|c|c|c|c|c|c|}
\hline \multirow[t]{2}{*}{ Parameters } & \multicolumn{4}{|c|}{ Treatments } & \multirow{2}{*}{ SEM } & \multirow{2}{*}{$\begin{array}{c}\text { Level of } \\
\text { significance }\end{array}$} \\
\hline & $\mathrm{T}_{0}$ & $\overline{T_{1}}$ & $\mathrm{~T}_{2}$ & $\mathbf{T}_{3}$ & & \\
\hline Live body weight (gm) & 1882.7 & 1827.9 & 1728.6 & 1725.8 & 31.06 & $* * *$ \\
\hline Egg production no/bird/week & 4.12 & 4.41 & 4.47 & 4.45 & 0.26 & NS \\
\hline Egg mass/bird/week $(\mathrm{kg})$ & 0.25 & 0.27 & 0.27 & 0.26 & 0.002 & NS \\
\hline Feed consumption/bird/week $(\mathrm{kg})$ & $0.76^{\mathrm{a}}$ & $0.66^{\mathrm{b}}$ & $0.78^{a}$ & $0.78^{\mathrm{a}}$ & 0.042 & $* *$ \\
\hline FCR & $2.58^{\mathrm{b}}$ & $2.48^{\mathrm{b}}$ & $2.68^{\mathrm{ab}}$ & $2.73^{\mathrm{a}}$ & 0.069 & * \\
\hline
\end{tabular}

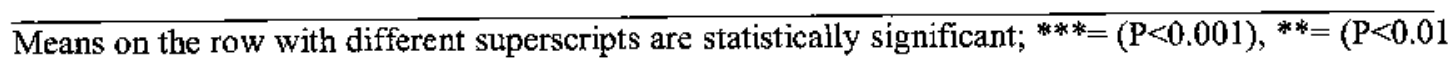
$\mathrm{NS}=$ Not Significant

Table 3. Effect of whole linseed on egg qualities of laying hens

\begin{tabular}{llllllc}
\hline \multirow{2}{*}{ Parameter } & \multicolumn{4}{c}{ Treatments } & \multirow{2}{*}{ SEM } & $\begin{array}{c}\text { Level of } \\
\text { significance }\end{array}$ \\
\cline { 2 - 5 } & \multicolumn{1}{c}{$\mathrm{T}_{0}$} & \multicolumn{1}{c}{$\mathrm{T}_{1}$} & $\mathrm{~T}_{2}$ & \multicolumn{1}{c}{$\mathrm{T}_{3}$} & & \\
Egg weight $(\mathrm{g})$ & $63.02 \pm 1$ & $62.10 \pm 0.9$ & $61.83 \pm 0.7$ & $61.38 \pm 0.9$ & 3.15 & $\mathrm{NS}$ \\
Egg yolk weight $(\mathrm{g})$ & $16.7 \pm 0.8$ & $16.22 \pm 0.6$ & $15.8 \pm 0.6$ & $16 \pm 0.7$ & 0.26 & $\mathrm{NS}$ \\
Haugh unit & $72.40 \pm 9.5$ & $70.66 \pm 8.3$ & $75.14 \pm 8.9$ & $79.59 \pm 5.2$ & 1.5 & $\mathrm{NS}$ \\
Yolk index & $0.42 \pm 0.01$ & $0.43 \pm 0.01$ & $0.43 \pm 0.03$ & $0.43 \pm 0.01$ & 0.09 & $\mathrm{NS}$ \\
Shell weight $(\mathrm{g})$ & $8.40 \pm 0.10$ & $8.28 \pm 0.10$ & $8.13 \pm 0.11$ & $8.10 \pm 0.11$ & 0.27 & $\mathrm{NS}$ \\
Shell thickness $(\mathrm{mm})$ & $0.40 \pm 0.01$ & $0.39 \pm 0.01$ & $0.38 \pm 0.02$ & $0.38 \pm 0.02$ & 0.005 & $\mathrm{NS}$ \\
\hline
\end{tabular}

NS-Non significant; SEM Standard error of mean 
Egg quality parameters aspects such as yolk weight, egg weight, HU, yolk index, shell weight and shell thickness were not influenced $(\mathrm{P}>0.05)$ by feeding linseed (Table 3). A trend for lower yolk weight was observed in birds fed $10 \%$ linseed, where as the highest yolk weight percentage was recorded in control diet. Haugh unit value is an acceptable measure of the quality and freshness of shell eggs. Eggs produced by layers fed the linseed $15 \%$ had the maximum value; where as those from $5 \%$ linseed had the minimum HU. There was no statistical difference among the different diets for yolk index. These results are consistent with the findings of Scheideler et al., (1998), Novak $\&$ Scheideler (2001), and Bean \& Leeson, (2003), who reported no change in these egg characteristics in layers fed diets containing linseed. On the other hand, Beynen (2004), and Sosin et al., (2006) reported that feeding layers with linseed reduced $(\mathrm{P}<0.05)$ egg weight, while yolk weight remained constant.

\section{Conclusion}

Based on the results of the present study, it may be concluded that feeding linseed to the laying hens has no detrimental effects on egg production and egg quality.

\section{References}

Ahmad, S., Ahsan-ul-Haque, Kamran, M., Ata-ur-Rehman, Z., Sohail, M.U. and Shahid-ur- Rahman. 2013. Effect of feeding whole linseed as a source of polyunsaturated fatty acids on performance and egg characteristics of laying hens kept at high ambient temperature. Rev.Bras.Cience.Avic. Vol.15, No.1. Campinas Jan-Mar. 2013.

Aymond, W.M., and Van Elswyk, M.E. 1995. Yolk thiobarbituric acid reactive substances and $\mathrm{n}-3$ fatty acids in response to whole and ground flaxseed. Poultry Sci. 74: 1388-1394.

Bhatty, R.S. 1995. Nutrient composition of whole flaxseed meal. Pages22-42 in flaxseed in human nutrition, S.C. Cunnane and L.U. Thompson, ed. Academic press, Champaign, IL.

Baucells, M.D., Crespo, N., Barrorta, A.C., Lopez-Ferrer, S and Grashorn, M.A. 2000. Incorporation of different polyunsaturated fatty acids into eggs. Poult.Sci. 79: 51-59.

Bean, L.D., and Leeson, S. 2003. Long term effects of feeding flaxseed on performance and egg fatty acid composition of brown and white hens. Poultry Science, 82: 388-394.

Beynen, A.C. 2004. Fatty acid composition of eggs produced by hens fed diets containing groundnut, soybean or linseed. New Zealand Journal of Animal Science. 52(1): 3-10.

Cherian, G. 2008. Omega 3 fatty acids: Studies in avains. Pages 169-178 in wild-type food in health promotion and disease prevention.

Haugh, R.R. 1937. The Haugh unit for measuring egg quality. US Egg Poult.Mag. 43: $522-555$

Kratzer, F.H. and Pran .Vohra. 1996. The use of flaxseed as a poultry feedstuff. Poultry fact sheet no-21. Monitoba Agriculture and Food, Animal Industry Branch, May, 1999.

Mazalli, M.R., Faria, D.E., Salvador, D and Ito, D.T. 2004. Acomparison of the feeding value of different sources of fats for laying 
hens. 2. Lipid, cholesterol anf vitamin E profiles of egg yolk. J. Appl. Poult. Res, 13: 280-290.

Manitoba Agriculture and Food, Animal Industry Branch, May, 1999. The use of flaxseed as poultry Feed stuffs. Poultry fact sheet no-2l.

Mazza. G. and Oomah, B.D. 1995. Flaxseed dietary fibre and cyanogens. In flax seed in human nutrition. S.C.Cunnane and L.U.Thompson (Eds). Aoes press, Champaign, IL,.2242.

Madhusudhan, K.T., Ramesh, H.P., Ogawa, T., Sasaoka, K. and Singh. N. 1986. Detoxification of commercial linseed meal for use in broiler rations. Poult. Sci. 65: 164-171.

Novak, C and Scheideler, S.E. 2001. Long term effects of feeding flaxseed based dietd. 1. Egg production parameters, components and egg shell quality in two strains of laying hens. Poul.Sci, 80: 1480-1489.
Scheideler, S.E and Froning, G.W. 1996. The combined influence of dietary flax seed variety, level, form and storage conditions on egg production and composition among vitamin-E supplemented hens. Poult. Sci.75: 1221-1226.

Scheideler, S.E., Jaroni, D and Froning, G. 1998. Strain and age effects on egg composition from hens fed diets rich in $\mathrm{n}-3$ fatty acid. Poult.Sci.77: 192-196.

Sosin, E., Borowiec, F. and Strzetelski, J. 2006. The effect of feeding regular or low a-linolenic acid linseed on the fatty acid composition of egg yolks. Journal of animal feed science. 15: 641-650.

SPSS, 2006. Statistical Package for Social Statistics version 16. SPSS Inc. Michigan Avenue, Chicago, USA. 